\title{
Research on multiple homicide in Hungary ${ }^{1}$
}

Nagy László Tibor ${ }^{2}$
Orsolya Bolyky

\section{ABSTRACT}

In this research we examined the criminological background of aggravated cases of the most serious crime against human life of outstanding severity, the crime of multiple homicide, in Hungary. Processing the full range of data of the period 2000-2012, we performed a detailed analysis of 217 cases, 250 perpetrators and 532 victims altogether. The research aimed to explore the legal assessment and the perpetration motives of the crime, the perpetrators' social and psychological backgrounds as well as the victims' characteristics.

Keywords: Family background. Long-standing conflicts. Mental illness. Alcohol consumption. Life imprisonment.

\section{INTRODUCTION}

Homicide against more than one person as an aggravated case of homicide is penalized under Section 160 (2) (f) of the Hungarian Criminal Code (Act C of 2012) in force. The crime of homicide against more than one person (multiple homicide) is committed when a perpetrator kills or attempts to kill several persons either simulta-

1 Data de recebimento: 18/07/2018. Data de aceite: 21/09/2018.

2 Senior Research Fellow, Heas of Crime Research and Analysis Division, National Institution of Criminology, Hungary. E-mail: nagy@okri.hu

3 Senior Research Fellow, Acting Deputy Head of Crime Resaearch and Analysis Division, National Institution of Criminology, Hungary. E-mail: nagy@okri.hu 
neously, with a single determination of will, or at subsequent times with different determinations of will (delictum complexum). The condition for establishing this aggravated case is that the acts be judged in single proceedings. At least two persons' death is required for the crime to qualify as completed. If, despite the attempt to kill, only one of the injured parties dies or all injured parties stay alive, the crime committed qualifies as an attempt of homicide against more than one person.

\section{TYPES OF THE CRIME AND}

\section{CIRCUMSTANCES OF PERPETRATION}

From the criminological point of view multiple homicide comprises the following major categories ${ }^{4}$ : Running amok is an act typically targeting to kill several persons at several locations, committed on a continuous basis. An amok runner kills any person he happens to encounter, so his behaviour is unpredictable; this is a kind of action series;

In the case of an act committed on several occasions there may pass several days, weeks or even longer periods between the respective instances of committing the crime and the injured parties are substantially not chosen at random. A special case of this category is what is referred to as serial homicide, when the criminal acts are committed on three or more different occasions;

Mass homicide means that the criminal act is committed at one location against at least four persons;

For the remaining other cases - which constitute the great majority of the cases - it is characteristic that the perpetrator kills the victims at the same time, one after the other (other multiple homicide).

Based on this typology, the distribution of the examined cases was

4 Ágnes Dr. Csernyikné Póth: A profilalkotás lényege. In: Ágnes Dr. Csernyikné Póth - Mihály Fogarasi (ed.): Kriminálpszichológia. Rejtjel Publisher, Budapest, 2006, p. 216. 
the following: running amok: 1.4\%; mass homicide: $3.7 \%$; act committed on several occasions: $12 \%$; other multiple homicide: $82.9 \%$. Thus the most dangerous categories of this crime of extraordinary severity together make up $17.1 \%$ of the cases, and fortunately the occurrence of the most unpredictable amok running is extremely rare in Hungary.

Of the homicides analysed, $85.6 \%$ were committed by a single perpetrator; there were more than two perpetrators only in $4.3 \%$ of the cases. Following from the nature of the crime the homicide or attempt of homicide was certainly committed against at least two victims; there were more than two injured parties in $30.4 \%$ of the cases.

There was completed homicide exclusively (when all the victims died) in $33.2 \%$ of the cases; $44.2 \%$ of the cases reached the stage of attempt only, while in $22.6 \%$ of the cases there were both completed and attempted homicides. On the whole, in somewhat more than half of the cases (55.8\%) at least one victim died.

It can be regarded as typical that defendants committed their criminal acts against familiar persons, often relatives or earlier partners: only one fifth (20.4\%) of the injured parties were unfamiliar with the perpetrator before, while $33.2 \%$ were relatives or earlier relatives of the perpetrator.

As regards the times of committing the crime, there are significant differences only considering the days of the week as weekends and holidays clearly stand out $(37,2 \%) ; 19.8 \%$ of the acts were committed on a Saturday; $15.7 \%$ on a Sunday, while $1.7 \%$ on a holiday. This indicates that there often develop conflicts between relatives or friends when spending their rest period together, frequently as a consequence of the influence of alcohol.

Merely $8.9 \%$ of the attacks against human life were committed without using a weapon, with just physical force. The weapons used were mostly knives or pocket knives (31.0\%); firearms (22.9\%); axes or choppers (9.2\%), or arson instruments (8.1\%). Poison was used against 16 injured parties (3.0\%). 
Exactly half of the perpetrators (50.0\%) were under the influence of some psychoactive substance when committing the act. Most of them had consumed alcohol (46.0\%), 7.2\% some psychiatric medication (antidepressant), while 6 persons (2.4\%) used drugs or a combination of these.

According to the forensic expert opinions, $24 \%$ of the defendants had an alcohol problem when committing the crime, while $6 \%$ had suffered from that before, but it was no longer detectable at the time of committing the crime. Also $2.4 \%$ of the perpetrators qualified as drug addicts and similarly $2.4 \%$ as regular (several times a week), and $0.8 \%$ as occasional drug consumers (consuming drugs mainly at weekends, when going out).

In the course of committing the criminal act, $27.6 \%$ of the perpetrators were injured: $18.8 \%$ suffered light, injuries while $8.8 \%$ had suffered serious injuries (healing in over 8 days).

After committing the crime, $30.4 \%$ of the perpetrators stayed at the scene of the crime and $32.0 \%$ left for their own apartment or place of residence, while $21.2 \%$ of the perpetrators went into hiding and 4.8\% left for abroad.

After committing the crime, 40 persons (16.0\%) attempted to commit suicide; as a consequence of which 27 of them (10.8\%) stayed alive, while 13 (5.2\%) lost their lives. Most of these persons (11) slit their wrists, others poisoned or shot themselves (8 persons respectively).

\section{THE SOCIODEMOGRAPHIC CHARACTERISTICS OF PERPETRATORS}

About the perpetrators $90.8 \%$ of them perpetrators were men and only $9.2 \%$ women. ${ }^{5}$ This indicates that among persons committing these more severe, often more brutal than the average, cases of mul-

$542.3 \%$ of the victims were women, so the rate of female victims is much higher than the rate of female perpetrators. 
tiple homicide, the rate of women is much lower than in the case of homicide in general. ${ }^{6}$

As regards age distribution most of the perpetrators were aged between 20-29 (32.8\%); 9 perpetrators (3.6\%) were minors (under 18), and 10 were above 60 (4.0\%) years old. The youngest perpetrator was 14 , and the oldest 79 . The age distribution of victims is significantly different from that of perpetrators. The rates of victims over 60 (19.4\%) and under 18 (16.9\%) are very high, which can be considered a sad fact because the most defenceless and vulnerable persons belong to these age groups. (The rate of children under 14 is $11.8 \%$.).

The overwhelming majority of the perpetrators, 231 (92.4\%) were Hungarian citizens; the rate of foreigners was only $7.6 \%$.

As regards family status, more than half of the perpetrators lived in a relationship. The rate of those living in cohabitation was 27.6\%; the rate of married perpetrators was $26.0 \%$ and that of unmarried perpetrators was $31.6 \%$ important to point out that. $35.2 \%$ of the perpetrators did not have any children and $18.8 \%$ did not cohabitate with their minor age children as the latter cohabitated with the perpetrator's divorced spouse or other relative or lived in state care.

Most perpetrators were primary school (8 grades) graduates (35.6\%), and the rate of vocational school graduates was almost the same (35.2\%). Ten perpetrators (4.0\%) were college of higher education or university graduates, while 26 persons (10.4\%) had not even completed a primary education. There were 61 perpetrators (24.4\%) who had started but not finished their studies, most of them (9.6\%) had left primary school unfinished.

The rate of those with permanent employment was very low, only $30.8 \%$. The rate of unemployed was $23.2 \%$; Of those with occasional work was $27.6 \%$. As regards their employment, most of the employed

6 According to Hungarian criminal statistical data, in 2013 the rate of women committing homicide was $18 \%$; according to some research this indicator occasionally reaches up to $24 \%$, cf. Mariann Kránitz: Emberölés: áldozatok és tettesek. Kriminológiai Tanulmányok volume 41, National Institute of Criminology, Budapest, 2004, p. 97. 
perpetrators were skilled (22.0\%), unskilled (13.2\%) or semiskilled workers (9.2\%). Employed perpetrators represented 8.4\%, self-employed $5.6 \%$, invalidity pensioners $7.2 \%$ and old-age pensioners $3.2 \%$. The data available indicate that $34 \%$ of the defendants had a poor, while $19.2 \%$ an extremely poor income and wealth status.

Also, 36.0\% of the perpetrators came from a village, 29.6\% from a small town, 17.2\% from a town or city with county rights (the 23 largest rural towns/cities in Hungary), 16.8\% from the capital and $0.4 \%$ from a farm settlement. Perpetrators' place of residence was typically the same as the scene of the crime they committed (67.6\%), and almost one third of them (30.8\%) committed the homicide in their own dwelling. ${ }^{7}$

About half (52.0\%) of the defendants proved to have no criminal record. Repeat offenders represented $31.6 \%$, recidivists $9.0 \%$, special recidivists (who committed the same or a similar criminal act within 3 years) are $2.9 \%$, while multiple recidivists $4.5 \%$. Ten persons (4.0\%) had committed homicide before, and $27.2 \%$ of the perpetrators had been sentenced to confinement to be served before.

\section{PERPETRATORS' MOTIVES}

In view of the special character of the crime examined, perpetrators' motives must be studied in relation to the victims and their number since in certain cases there may arise several different motives on the part of the perpetrator (e.g. when one of the injured parties is killed for financial gain and the other, who caught the perpetrator in the act, with the purpose of concealing the crime).

As regards the major perpetration motives - considering the categories set up in the technical literature ${ }^{8}$ - of the acts examined during the research, 38.4\% were conflict-related, $21.3 \%$ situational,

$756.3 \%$ of the injured parties stayed at their own dwellings when the crime was committed. In the case of violence against relatives, the dwelling of the perpetrator and the injured party was often the same. 8 Antal Bakóczi: Az emberölés. Közgazdasági és Jogi Könyvkiadó Publisher, Budapest, 1984, pp. 96-97. 
15.3\% committed for financial gain, $4.9 \%$ with the aim to conceal the crime and $0.4 \%$ had a sexual aspect. In the case of homicide against several persons we complemented the above typology with two further types: extended suicides, and delicts where the motive was not to be established or there were other motives. The rate of extended suicides was $8.8 \%$, while in $10.9 \%$ of the acts the motive was not to be established clearly or there were other motives.

Conflict-related homicide is characterised by chronicity: a continuous or permanent discord or crisis situation and the accumulation of emotions for a long time. Homicides committed by women are also constituted by this major type of a relatively easy to define nature. This is characterised by a permanent crisis state mainly related to persons who are physically and psychologically close to the perpetrator. The circle of victims comprises related persons first of all; primarily and in the majority of the cases the husband, cohabiting partner or lover, secondly the child, thirdly the parents and other relatives. In every case the crime grows out of the personal relationship with the victim and is usually generated by deep distress which intensifies to the point when the perpetrator's scope of action shrinks and she is unable to see another alternative to homicide. ${ }^{9}$ For this reason, these perpetrators are also referred to as "crisis criminals". ${ }^{10}$

The cases of homicide arising from longstanding conflict relations examined in our research are actually the most extreme forms of family violence (in $43 \%$ of the victims). This violence manifested itself mostly in still existing relationships between separating partners or ex-partners. As was revealed in the cases, both the perpetrators and the victims had in the course of the long years they had spent together, regularly used violence against each other. Homicide often occurred as a consequence of the accumulated tension in the course of a seemingly insignificant dispute, in an extremely upset state. It

9 Raskó Gabriella: A noi bunözés. Közgazdasági és Jogi Könyvkiadó Publisher, Budapest, 1978, pp. 361-362.

10 Ernst Seelig: Lehrbuch der Kriminologie. Darmstadt, 1964, p. 132. 
must be emphasised that it was in these cases where the contribution on the victims' part was the highest and usually meant the victim's provocative behaviour. There were also cases at the same time when the perpetrator planned the criminal act in advance and/or often arranged a partner for the implementation. Since this research focuses on multiple homicide, in the case of criminal acts against women we often found (20.2\% of the cases against women) that children became victims simultaneously. It must be added at the same time that in $45 \%$ of the cases of homicide against children was committed by mothers.

In the sample we analysed, even acts explicitly motivated by jealousy were mainly related to male perpetrators; $8.7 \%$ of the perpetrators committed the homicide out of jealousy. It can be mentioned as a typical antecedent of homicide that the perpetrator was unable to accept the woman's breaking up the relationship or her new partner even if though the perpetrators themselves often established a new relationship, too. Here you usually cannot speak of true love; instead the homicide act is facilitated by possessiveness, the inability to accept separation and various attachment disorders. In these cases you can find explicitly well-situated perpetrators, including some with a higher education degree and no criminal record. It must be added that some of the revenge homicide cases in fact had the same roots. A typical case of this is when a perpetrator kills the common child in order to punish the ex-partner. A "jealous" perpetrator often commits the act under the "encouraging" - in fact aggression enhancing effect - of alcohol.

The situational category of homicide comprises homicide acts arising from ad-hoc, episode-like conflicts thus without a longer antecedent and involving an outburst of passion (in the majority of cases in a drunken state). This category includes "short circuit-like" affective (reactive) homicides, too. These acts are mainly characterised by an inconsiderate way of releasing suddenly generated high emotional tension. In the case of these acts, provocation from 
the victims' part is often also evident, and many times it is only the accidental development of circumstances that determines which of the two participants is the perpetrator and which is the victim. In our research we primarily listed under revenge acts situational homicide cases in the case of which the perpetrator assigned exaggerated significance to an assumed grievance or to one of insignificant weight. As a main characteristic, at the time of committing these crimes both the perpetrator and the victim are in a drunken state. There typically was an argument in or near a pub, after which the "settlement of the conflict" started with a fight or scrum, in the course of which the would-be perpetrator pulled out a knife and used it in the scrum. The intention is usually only potential harm and in the majority of cases stays only an attempt. Due to the influence of alcohol, a provocative contribution on the victim's part is frequent, too.

The motif of revenge is qualified in criminal law as an aggravated case of homicide committed with a malicious aforethought or motif. According to Resolution of Uniformity No. 3/2013 ${ }^{11}$ of the Curia malicious aforethought or motif means acts arising from a morally rejectable motif. Homicides committed with morally rejectable motifs typically include homicides committed as sexual offences as well as some of the revenge homicides. The judgement of revenge depends on the nature of the reason that generates the passion in the perpetrator for committing the crime. If the perpetrator exercises quasi private justice or acts out of love-related jealousy, this in itself is insufficient for establishing a malicious motif. If, on the other hand, the victim is killed out of fear that a crime may be revealed, establishing a malicious motif may be well-grounded.

The motif of financial gain was relatively underrepresented in the sample: only $15.9 \%$ of the perpetrators were motivated by financial gain. This is the motif where it can be most often observed that the perpetrator did not know the victim prior to the crime $(41 \%$ of the

11 Point 3 of Part 2 of Decision 3/2013 BJE. 
victims of crimes motivated by financial gain). Within the category of homicide for financial gain there are two types: one of them comprises homicide committed in the course of robbery through burglary (46.1\% of the victims of homicide for financial gain) or robbery in the street (47.6\%). In most cases the scene of the crimes is a village or small town where people know one another and are familiar with one another's habits: they know who has savings or other valuables at home. A typical method is when the perpetrators - usually minors or young adults acting at night - break into the homes of elderly and defenceless people and search for valuables. If the victims are woken by the noise, they attack them by any tool or knife found at the scene. These acts usually do not generate great financial gain; often the perpetrators leave with empty hands. As regards the perpetrator method they are committed causing above average suffering to the victim, so in many cases peculiar cruelty is also established in addition to financial gain. While the average age of victims of homicides for financial gain was 52, in the case of other homicides, victims' average age was as young as 34. It can thus be established that in Hungary, mainly older generations are potential victims of multiple homicide.

The other type of perpetration for financial gain is contract homicide (4\% of perpetrators) in the classic sense of the word. The perpetrator undertakes to kill or assist in killing the person specified for money. It must be noted that the latter was more frequent, i.e. that the contractor and the contracted perpetrator committed the crime together. Contracted homicide cases also include cases of murder in the underworld.

Homicide usually stopped at the attempt stage also in cases where families at feud "declared war" against each other due to another insult or abuse. Acts of this kind almost exclusively occurred in families of Roma ethnic origin or where members of families of the Roma minority attacked potential non-Roma victims. The witness and suspect interrogations revealed that, according to a Gypsy tradition, 
an insult against a family member is revenged by the whole small community, the family. Family members attack the family they are enemies with using garden tools and sticks, so the clash results in several persons injured or, in worse cases, killed. Also in these cases, alcohol has a significant role in perpetration.

There were no explicitly sexually motivated acts in the period examined. Homicide for the implementation of sexual crime, the perpetration of violent crimes with a motif against sexual freedom, or homicide with the purpose of increasing sexual desire all qualify as homicide committed with particular cruelty. ${ }^{12}$ In our sample there was only one case who was the victim of a sexual crime. Considering her age of 67 years additional motives like perturbation, revenge or anger may also arise.

A separate group is made up of cases where the perpetrator acted in response to an assumed or actual attack against him/herself or another person but the act does not qualify as justifiable defence nevertheless. Such cases include homicide committed as a disproportionate response in self defence and cases where proceedings were started for the application of unlawfully established defence facilities used by one party against the other in Roma-non Roma conflicts. In the use of this latter method usually nobody was injured but there was the danger of life-threatening injuries. The defence facility was typically an active electric wire around a plot.

The category of multiple homicide of an ideological nature comprises cases with a political or religious background. ${ }^{13}$ Such cases are rather rare in Hungary, although a series of murders against Romani people was committed in the period examined. At the same time, the criminal proceedings were not finally completed at the time of our research. ${ }^{14}$

12 Point 3 of Part 2 of Decision 3/2013 BJE.

13 Antal Bakóczi: Id. pp. 98-99.

14 In 2008-2009, perpetrators carried out armed attacks against Roma homes at nine scenes; six persons including a child died, while five were seriously injured. 
In the case of extended suicide the perpetrator commits homicide with a single determination of will, in an uninterrupted series of acts, against one or several persons who are usually emotionally close to the perpetrator, before killing him/herself. Within this circle, jealousy was the most frequent motif in the case of men, while for women it was despair and a psychotic state developing simultaneously that led to committing the act. There were 19 cases of extended suicides (8.8\% of all the cases examined in this research), in 10 out of which the perpetrator successfully committed suicide after the homicide, while in 9 cases the suicide stopped at the attempt stage and criminal proceedings were conducted against the perpetrators. Among the perpetrators there were 13 men and 6 women, so female perpetrators are overrepresented in this category. The perpetrators' average age was 42 , which is higher than the average age of perpetrators committing other wilful homicide. ${ }^{15}$ Stayed alive $30.8 \%$ of the men and $66.7 \%$ of the women stayed alive, which proves that the acts committed by women should rather be interpreted as a cry for help than an actual attempt of suicide. Four perpetrators were sentenced to imprisonment by the court as, even though to a limited extent, they were compos mentis. The others committed their act in a state of mental disorder, typically schizophrenia, so they were acquitted by the court and, with one exception, sentenced to involuntary treatment at a mental institution. Extended suicides claimed the lives of 25 victims altogether, while 20 survived.

In several cases no specific motives could be established in fact; not even ad-hoc, situational disagreements or arguments. In the case of such delicts there were mainly the influence of alcohol and factors in the perpetrators' personalities in the background of the acts.

At the same time, one cannot but share the opinion that "criminal acts whose specific reasons cannot be established with reference to

15 The average age of perpetrators committing multiple homicide was 34.9 years. The average age of perpetrators committing wilful homicide was 35.5 in 2012 and 36.2 in 2013. 
the victims or the circumstances cannot be regarded as fully accidental from the criminological point of view, considering motivating factors to be established on the perpetrator's side". ${ }^{16}$

The majority of the perpetrators in the analysed cases are characterised by low schooling, the lack of vocational training, unemployment or ad-hoc jobs and precarious existence arising from these. Their general personality characteristics include low intellect, the instability of emotions and passions, sociopathic or psychopathic personality disorder, adjustment difficulties, aggressive tension release and a low frustration tolerance level. Many of them are alcohol addicts or regular alcohol consumers, while in several cases the consumption of various medication (most often sleeping pills or sedatives) with alcohol or their misuse are characteristic. There were few drug consumers or addicts in the sample.

\section{THE OCCURRENCE OF MENTAL ILLNESS IN THE SAMPLE}

According to the final verdicts $76.0 \%$ of the defendants were fully compos mentis; $6.8 \%$ had a slight, $4.4 \%$ a medium and 1.2 a high degree of mental disability; $5,6 \%$ could not be regarded as mentally sane, while in the case of $6.0 \%$ no data could be established with reference to this.

In the majority of cases of acquittal due to mental disorder (13), the perpetrators suffered from paranoid schizophrenia and committed their act against family members. In the case of several perpetrators, the symptoms had first emerged only one-two weeks prior to the crime. Slightly limited mental capacity was mostly established in cases of personality disorder or dementia usually caused by alcohol dependence. A medium degree of mental ability and impaired awareness as restricting factors were rare. The diagnosis of

16 László Korinek: Kriminológia. Volume II. Magyar Közlöny Lap- és Könyvkiadó publisher, Budapest, 2010 , p. 90. 
imbecility or bordering on that is frequent in the expert opinions but is in the majority of the cases not qualified as a factor limiting mental ability with reference to homicide; it is potentially only considered as a mitigating circumstance.

The majority of perpetrators with mental disorders were 29-39 years old at the time of committing the crime; only two of them belonged to older age groups.

Perpetrators with mental disorder typically had no criminal record (11 persons), which proves that the conscious elaboration of unlawful conduct was far from them; their homicidal act occurred as a result of their mental state exclusively. In the majority of cases they committed the act at home. In the non-compos mentis group alcohol or drug consumption are not characteristic, either: neither when committing the crime, nor in general.

In the case of the majority of perpetrators there could typically be established a personality disorder that did not restrict their criminal liability, however. This personality disorder often meant that the personality structure of the person concerned was distorted; his/her intellect belonged to the category of low intellect; s/he was a disharmonic personality with a tendency to aggression and impulsiveness and antisocial elements. In the case of personalities who were less differentiated in the first place, the influence of alcohol usually played an important role.

\section{THE CRIMINAL PROSECUTION OF DEFENDANTS}

From of the criminal cases examined, $78,8 \%$ were concluded with a final decision establishing guilt and 6\% with acquittal due to mental disease. In $7.4 \%$ of the proceedings the perpetrator could not be identified or the defendant could not be declared guilty.

According to the perpetration structure, the rate of perpetrators was $72.8 \%$; coactors made up 22.0\%; accomplices 3,6\%; abettors 1.6\%. 
Also, 56.0\% of the perpetrators were caught within 24 hours $(30.8 \%$ within one hour) after committing the first homicide. There were 3 defendants who were arrested by the police more than 10 years after the crime. Most often (34.6\%) 2-3 years (24-35 months) passed from the time of committing the crime to the time the court decision took effect; $7-8 \%$ of the defendants had to wait more than 5 years for this.

In the course of the criminal proceedings, $42.5 \%$ of the defendants made a full and $29.8 \%$ a partial confession, while $27.7 \%$ denied the charges brought against them.

In the cases brought before the court, $29.9 \%$ of the defendants were sentenced to life imprisonment; of these, 18 persons (7.8\%) to life imprisonment without parole. In the case of those not sentenced to life imprisonment without parole, the earliest date of release on parole was established in 30 years in the majority of the cases (47\%), while there was even a term of 45 years. As regards the punishment of fixed-term imprisonment, punishments of between 10 -15 years were the most frequent (24.7\%). The court ordered involuntary treatment in a mental institution against 12 defendants (5.2\%).

\section{CONCLUSION}

In our research, whose findings only partially confirmed our hypotheses, we succeeded in exploring the basic characteristics and criteria of the specific type of crime analysed that may help aspects of prevention. Among the cases examined, the categories with the highest occurrence were homicides typically committed against family members due to long-standing conflicts, various situational acts, confrontations between characteristically drunken perpetrators and acts for financial gain.

It can be established that a differentiated picture must be drawn even of this crime of outstanding severity from the point of view of criminal law. This differentiated nature was also reflected by the 
wide spectrum of the terms of the imposed punishments, ranging from suspended imprisonment to the most serious punishment of life imprisonment without parole.

Fortunately, the actual occurrence of unpredictable amok running, which poses the greatest risk to society and thus generates increased fear, and of mass homicide and serial homicide cases of higher severity, is relatively rare.

The delicts typically take place against known victims, at the settlements where the victims live, most often in an apartment or a family house, on a Saturday or a Sunday. In the majority of the criminal acts the perpetrators were found in a short time and admitted having committed the crime.

The majority of perpetrators had criminal liability; at the same time they were persons struggling with psychological disorders, a disharmonic personality structure, a psychopathic lifestyle, low emotional intelligence and a lack of empathy skills, who in many of the cases released long accumulating tension when committing the crime.

The main direction of prevention may thus be developing the mental and psychiatric care system and assigning increased attention, including notifying those in authority, of the part of the family and the home environment. Essential crime prevention aspects are the early detection of psychological risk factors, which could be facilitated by the training of authority officials and public institution employees as well as by awareness raising and education efforts.

The psychological prevention of aggressive and antisocial behaviour in the case of children is especially important also for the future. Such behaviour develops slowly, in the course of years, while individual, family and environmental risk factors grow and their effects accumulate. Important tasks in prevention programmes are to reduce risk factors and reinforce protective factors. Primary prevention serves the preservation of children's physical and psychological health, while secondary prevention targets providing care for those showing 
early symptoms e.g. by developing and enhancing empathy skills. Social and economic security, too, can certainly facilitate constructing a society where aggression is scaled down, human life is more appreciated and human values are more prevalent.

\section{PESQUISA SOBRE MULTIPLOS HOMICÍCIOS NA HUNGRIA}

\section{RESUMO}

Neste artigo examinamos o histórico criminológico de casos agravados do mais sério crime contra a vida humana por sua excepcional gravidade, crimes de homicídios múltiplos, ocorridos na Hungria. Processando o espectro total de dados no período entre 2000-2012, observa-se uma análise detalhada de 217 casos, 250 perpetradores e 532 vítimas. O artigo objetiva explorar a avaliação legal e os motivos de execução deste crime, os antecedentes sociais e psicológicos dos seus autores assim como as características das vítimas.

Palavras-chave: Histórico familiar. Conflitos de longa duração. Doença mental. Consumo de álcool. Prisão perpétua.

\section{REFERENCES}

BAKÓCZI, Antal: Az emberölés. Közgazdasági és Jogi Könyvkiadó Publisher, Budapest, 1984

CSERNYIKNÉ PÓTH, Ágnes: A profilalkotás lényege. In: Ágnes Dr. Csernyikné Póth - Mihály Fogarasi (ed.): Kriminálpszichológia. Rejtjel Publisher, Budapest, 2006, pp. 213-217

KORINEK, László: Kriminológia. Volume II. Magyar Közlöny Lap- és Könyvkiadó publisher, Budapest, 2010.

KRÁNITZ, Mariann: Emberölés: áldozatok és tettesek. Kriminológiai Tanulmányok volume 41, National Institute of Criminology, Budapest, 2004, 
pp. $92-113$

RASKÓ, Gabriella: A noi bunözés. Közgazdasági és Jogi Könyvkiadó Publisher, Budapest, 1978

SEELIG, Ernst: Lehrbuch der Kriminologie. Darmstadt, 1964. 